\title{
Penyelesaian Pelanggaran Berat HAM Masa Lalu sebagai Pelaksanaan Pasal 28I ayat (2) UUD NRI Tahun 1945
}

\author{
Completion of Gross violation of Past Human Rights as the \\ Implementation of Article 28 paragraph (2) the 1945 Constitution of the \\ Republic of Indonesia
}

\author{
Ahmad Hambali \\ Fakultas Hukum Universitas Jayabaya
}

Jln. Pulomas Selatan Kav. 23, Jakarta Timur, Jakarta, 13210, Indonesia. Tel./Fax:+62-21-4212429 E-mail:ahbl474@gmail.com

Submitted: Jun 27, 2015; Reviewed: Jul 18, 2015; Accepted: Aug 3, 2015

\begin{abstract}
In the life of the nation, the 1945 Constitution of the Republic of Indonesia as the basic law is the only reference for the government and society as a cornerstone of life movement. A waiver of the provisions of the Constitution and the rules for the government in particular will have implications for the emergence of the most serious violations of the law suit that led to impeachment. Therefore, there should be none of the promise the government violated the constitution which can moreover it was related to obligations of law enforcement within the framework of the laws and principles of human rights, one of which is about the right not to be subject to discrimination that is clearly stated emphatically the 1945 Constitution. Since the New Order government many events in which gross violations of human rights, end, none of government after the subsequent obligations and the principles are right and proper. As a result, not only the Constitution is being violated, but the various problems of the past clot stuffed smooth movement towards the future of this nation.
\end{abstract}

Keywords: Constitution; Constitutional Rights; Human Rights; Gross Violation of Human Rights

Abstrak: Dalam kehidupan berbangsa dan bernegara, Undang-Undang Dasar Negara Republik Indonesia Tahun 1945 sebagai hukum dasar merupakan satu-satunya acuan bagi pemerintah dan masyarakat sebagai landasan gerak kehidupan. Pengabaian terhadap ketentuan dan aturan Konstitusi khususnya bagi pemerintah akan berimplikasi munculnya gugatan pelanggaran hukum paling serius yang menyebabkan pemakzulan. Oleh karena itu, tidak boleh ada satupun dari janji konstitusi yang dapat dilanggar pemerintah apalagi hal tersebut terkait dengan kewajiban penegakan hukum dalam kerangka negara hukum dan prinsip hak asasi manusia (HAM) yang salah satunya adalah tentang hak untuk tidak diperlakukan diskriminatif yang secara jelas dinyatakan tegas dalam Konstitusi RI. Sejak pemerintahan orde baru yang didalamnya banyak terjadi peristiwa pelanggaran berat HAM, berakhir, tidak satupun pemerintahan sesudahnya menjalankan kewajiban dan prinsip tersebut secara benar dan patut. Akibatnya tidak hanya Konstitusi yang dilanggar, akan tetapi berbagai persoalan masa lalu menggumpal menyumpal lancarnya gerak bangsa ini menuju masa depan.

Kata Kunci: Hak Asasi Manusia; Hak Konstitusional; Konstitusi; Pelanggaran Berat HAM 


\section{PENDAHULUAN}

Undang-Undang Dasar Negara Republik Indonesia Tahun 1945 (UUD NRI 1945) merupakan landasan utama bangsa dan pemerintahan Indonesia dalam bertindak. Konstitusi secara tegas mengatur dasar dari tata kehidupan bernegara masyarakat dan bangsa Indonesia. Satu di antara sekian banyak kesepakatan dasar tertulis yang terdapat dalam konstitusi, antara lain penegasan Indonesia sebagai negara hukum (rechtstaat). Karena amanat konstitusi tersebut, berbagai peraturan perundang-undangan dilahirkan untuk menopang setiap tindakan dalam seluruh kehidupan masyarakat dan bernegara agar selalu bersandar pada hukum. Negara hukum memiliki makna, antara lain: Pertama, pengakuan hak-hak asasi manusia (grondrechten); Kedua, pemisahan kekuasaan (scheiding van machten); Ketiga, pemerintahan berdasar atas undang-undang (wetmatigheid van het bestuur); dan Keempat, peradilan administrasi (administratieve rechtspraak). ${ }^{1}$

Bisa disimpulkan bahwa tidak ada negara hukum tanpa pemerintahan yang bertindak berdasarkan hukum. Juga tidak ada negara hukum bila tanpa jaminan terhadap hak asasi manusia, karena itulah kewajiban pemerintahan untuk menegakan hukum dan memberi jaminan terhadap perlindungan hak asasi manusia menjadi salah satu klausul utama dalam konstitusi sebagai dasar negara Republik Indonesia. Dengan demikian, penegakan hukum dan pertanggungjawaban setiap orang atau badan hukum terhadap pelanggaran hukum dan hak asasi manusia

Robert Mohl, Two Concepts of the Rule of Law, Indianapolis: Liberty Fund Inc., 1973, hal. 22. harus menjadi agenda utama untuk dilaksanakan.

Manusia juga memiliki hak asasi yang tidak bisa dikurangi dalam kondisi apapun (non-derogable rights), sebagaimana diatur dalam Pasal 28I ayat (1) UUD NRI 1945 yang meliputi:

Hak untuk hidup, hak untuk tidak disiksa, hak kemerdekaan pikiran dan hati nurani, hak beragama, hak untuk tidak diperbudak, hak untuk diakui sebagai pribadi di hadapan hukum, dan hak untuk tidak dituntut atas dasar hukum yang berlaku surut adalah hak asasi manusia yang tidak dapat dikurangi dalam keadaan apapun.

Karena hak-hak konstitusional tersebut, setiap manusia berhak mendapat perlindungan efektif dari negara. Kewajiban negara dalam menjamin dan melindungi setiap hak asasi warganya ini dapat menyebabkan gugatan bila tidak ditunaikan. Hal ini disebabkan karena negara yang diberi mandat rakyat untuk melayani dan melindungi warganya dianggap gagal menjalankannya. Kegagalan negara berupa pengabaian (ommission) jaminan perlindungan HAM warganya adalah bentuk yang lain dari pelanggaran HAM, sementara pada pelanggaran seriusnya, negara menjadi pihak yang melakukan pelanggaran terhadap hak asasi warganya.

Dalam hal tindakan pelanggaran HAM dan bahkan tindak kejahatan negara termasuk dalam kasus-kasus pelanggaran berat hak asasi manusia yang pernah terjadi, terdapat serangkain tindakan negara yang diduga secara sengaja dilakukan pada masa orde baru. Berbagai kasus tersebut hingga kini luput dan gagal dipertanggungjawabkan secara berkeadilan. Padahal dalam konteks 
negara hukum yang melindungi hak asasi manusia, pelanggaran serius terhadap hak asasi tersebut jelas tetap harus dipertanggungjawabkan sesuai aturan yang berlaku. Apalagi hal itu secara eksplisit juga dijamin secara tegas dan beruntun dalam pasal-pasal yang memuat hak asasi manusia dalam konstitusi, yaitu:

1. Pasal 28D ayat (1) menegaskan, setiap orang berhak atas pengakuan, jaminan, perlindungan, dan kepastian hukum yang adil serta perlakuan yang sama di hadapan hukum.

2. Pasal 28I ayat (1) yang mengatur bahwa hak untuk hidup, hak untuk tidak disiksa, hak kemerdekaan pikiran dan hati nurani, hak beragama, hak untuk tidak diperbudak, hak untuk diakui sebagai pribadi di hadapan hukum, dan hak untuk tidak dituntut atas dasar hukum yang berlaku surut adalah hak asasi manusia yang tidak dapat dikurangi dalam keadaan apa pun.

3. 28I ayat (2) menegaskan bahwa setiap orang berhak bebas dari perlakuan yang bersifat diskriminatif atas dasar apa pun dan berhak mendapatkan perlindungan terhadap perlakuan yang bersifat diskriminatif itu.

4. 28I ayat (4) yang menegaskan bahwa perlindungan, pemajuan, penegakan, dan pemenuhan hak asasi manusia adalah tanggung jawab negara, terutama pemerintah.

Penghindaran atas upaya pertanggungjawaban kasus pelanggaran berat HAM masa lalu akan menjadi persoalan serius, karena negara akan dianggap melakukan pelanggaran atas berbagai ketentuan konstitusi yang telah disebut di atas. Tidak hanya itu, negara juga dianggap melakukan tindakan diskriminasi penanganan kasus sebagaimana diatur dalam Pasal 28I ayat (2), di mana setiap warga negara dijamin haknya untuk bebas dari perlakuan yang bersifat diskriminatif atas dasar apa pun dan berhak mendapatkan perlindungan terhadap perlakuan yang bersifat diskriminatif itu.

Berdasarkan uraian di atas, maka objek analisis dalam tulisan ini adalah: Pertama, terkait kasus-kasus pelanggaran berat HAM yang pernah terjadi di Indonesia; Kedua, praktik "setengah hati" penyelesaian pelanggaran berat HAM masa lalu oleh pemerintahan sesudahnya; Ketiga, relevansi pelaksanaan Pasal 28I ayat (2) UUD NRI 1945 dalam penyelesaian pelanggaran berat HAM masa lalu.

\section{ANALISIS DAN PEMBAHASAN \\ Pelangaran Berat Hak Asasi Manusia Masa Lalu}

Pelanggaran hak asasi manusia dimaknai sebagai setiap perbuatan seseorang atau kelompok orang termasuk aparat negara baik disengaja maupun tidak sengaja, atau kelalaian yang secara melawan hukum mengurangi, menghalangi, membatasi, dan atau mencabut hak asasi manusia seseorang atau kelompok orang yang dijamin oleh undang-undang ini, dan tidak mendapatkan, atau dikhawatirkan tidak akan memperoleh penyelesaian hukum yang adil dan benar, berdasarkan mekanisme hukum yang berlaku. ${ }^{2}$ Definisi pelanggaran HAM juga disebut dalam UU No.26 Tahun 2000 tentang Pengadilan Hak Asasi Manusia

2 Pasal 1 ayat 6, UU No.39 tahun 1999 tentang HAM. LN 3886 
bahwat pelanggaran HAM berat (gross violation of human rights) meliputi kejahatan genosida dan kejahatan terhadap kemanusiaan. ${ }^{3}$

Tindak pelanggaran berat HAM di Indonesia diduga kuat pernah terjadi pada masa lalu yakni ketika orde baru berkuasa dengan cara yang otoriter yang mengutamakan stabilitas politik dan pendekatan keamanan. Pelanggaran berat HAM yang terjadi pada masa orde baru inilah yang menjadi fokus dan batasan penelitian penulis untuk diteliti secara mendalam. Akibat pelanggaran berat HAM ini banyak masyarakat yang dianggap melawan keinginan pemerintah menjadi korban baik dibunuh, ditahan dan ditangkap maupun dihilangkan secara paksa dan tindakan lainnya yang pernah terjadi sejak 1965 hingga 1998.

Orde Baru sendiri dapat didefinisikan sebagai masa pemerintahan Presiden Soeharto di Indonesia yang berlangsung dari tahun 1968 hingga 1998. Orde Baru menggantikan Orde Lama yang merujuk kepada era pemerintahan Soekarno ${ }^{4}$ yang dalam banyak penelitian, peralihan kekuasaannya disebut dilakukan dengan kudeta merangkak (creepin coup). ${ }^{5}$ Orde Baru hadir pada awalnya bermaksud melakukan "koreksi total" atas penyimpangan yang dilakukan Orde Lama Soekarno. Namun yang terjadi berbagai penyalahgunaan kekuasaan yang menimbulkan banyak korban dibarengi praktik

3 Pasal 7, 8 dan 9 UU No.26 tahun 2000 tentang Pengadilan HAM. LN 208

4 Wikipedia, "Orde Baru," sebagaimana dikutip pada laman website: http://id.wikipedia.org/wiki/ Orde baru, [Diakses, 10 Maret 2008].

5 Dapat dilihat dalam Sukmawati Sukarno, Creeping coup d'etat Mayjen Suharto: Kesaksian HariHari Terakhir Bersama Bapak, Jakarta: Yayasan Bung Karno, 2011. korupsi terjadi di era Orde Baru. Selain itu, kesenjangan antara rakyat yang kaya dan miskin juga semakin melebar. Parahnya semua penyalahgunaan dan penyimpangan yang muncul dilengkapi dengan berbagai tindak kekerasan yang hingga kini belum pernah dipertanggungjawabkan secara bijak, patut dan adil.

Selain diselenggarakan untuk menghadapi lawan-lawan politik orde baru, pelanggaran berat HAM berupa tindak kekerasan negara juga dilakukan sebagai bagian dari kampanye penguatan keamanan dan stabilitas politik bahkan dijadikan sebagai shock terapy ${ }^{6}$ yang menjadi salah satu cara melindungi kepentingan pemerintah terhadap tuntutan-tuntukan rakyat yang meminta hak-hak atas tanah, upah yang lebih tinggi, reformasi politik dan sebagainya.

Dengan berbagai rangkaian tindakan kekerasan tersebut, rezim Soeharto telah berhasil melembagakan teror dalam tubuh negara, antara lain dengan mencap oposisi kritis sebagai "komunis", "ekstrem kanan", "pembangkang" dan lain sebagainya dengan menggunakan kekuatan militer dan paramiliter untuk melawan pemrotes serta kelompok separatis jika perlu.

\footnotetext{
6 Pernyataan ini antara lain dinyatakan oleh Soeharto dalam menyikapi peristiwa pembunuhan misterius (Petrus) yaitu tindakan pelanggaran hak hidup yang dilakukan negara terhadap masyarakat yang dituduh sebagai pelaku kriminal. Dalam sebuah memoarnya, Soeharto menyatakan: "Lalu ada yang mayatnya ditinggalkan begitu saja. Itu untuk shock therapy, terapi goncangan. Supaya, orang banyak mengerti bahwa terhadap perbuatan jahat masih ada yang bertindak dan mengatasinya. Tindakan itu dilakukan supaya bisa menumpas semua kejahatan yang sudah melampaui batas perikemanusiaan itu. ” Dalam G. Dwipayana dan Ramadhan KH, Soeharto: Pikiran, Ucapan dan Tindakan Saya, Jakarta: Citra Lamtoro Gung Persada, 1989, hal. 390.
} 
Data yang dihimpun menyebutkan bahwa sedikitnya satu juta lebih korban tewas pada peristiwa $65(1965-1966)^{7}, 100.000$ orang jiwa tewas pada masa Daerah Operasi Militer (DOM) Papua (1963-1987) ${ }^{8}, 200.000$ orang di Timor-Timur (1975-1999) ${ }^{9}, 10.000$ orang tewas akibat penembakan misterius $(1983-1986)^{10}, 1000$ orang tewas pada pemaksaan politik ideologi Pancasila (19781989) ${ }^{11}, 1321$ tewas pada DOM Aceh (1989$1998)^{12}, 16$ orang di 27 Juli $1997^{13}$, 528 orang diculik, 2000-an orang tewas pada kasus kerusuhan sistematis Mei, Trisakti, Semanggi I dan II $^{14}$ dan banyak lagi.

Rentang peristiwa pelanggaran HAM pada masa Orde Baru juga bisa dilihat dari periode peristiwa pelanggaran HAM yang dikemukakan Satya Arinanto yakni pada kasus pelanggaran berat HAM di Tanjung Priok (12 September 1984), pelanggaran HAM DOM Aceh 1989-1999, pelanggaran berat HAM di Timor-Timur, Trisakti (12 Mei 1998), Semanggi I (13 November 1998), Se-

Richard Tanter, Intelligence Agencies and Third World Militarization: A Case Study of Indonesia, Dept. of Politics Faculty of Economic and Politics Monash University 1991, hlm. 26 dan134. Untuk mengilustrasikan banyaknya korban yang jatuh pada saat itu, seorang filsuf terkenal, Bertrand Russell, ditahun 1966 mengatakan “...in four months, five times as many people died in Indonesia as in Vietnam in twelve years." Dalam Peter Dale Scott, "The United States and the Overthrow of Sukarno," 1965-1967," Pacific Affairs, 58, Summer 1985, hlm. 239.

8 Perkiraan ELSHAM Papua

9 Tanter, Op.Cit

10 Ibid.

11 Laporan Komnas HAM, "Pengkajian Pelanggaran HAM Orde Baru,” Jakarta: 2003, hlm. 17.

12 Laporan Koalisi NGO HAM Aceh "Pola Pelanggaran HAM Aceh masa DOM," Aceh: 2000, hlm. 5.

13 Laporan KontraS, "27 Juli sebagai Kerusuhan Sistematis," Jakarta: 2000, hlm. 4.

14 Laporan TGPF Kerusuhan Mei 1998. manggi II, 22-24 September 1999. ${ }^{15}$

Dari beberapa data statistik di atas, penulis melihat bahwa kasus kekerasan negara terutama yang berlangsung selama Orde Baru memiliki design kekerasan negara yang khas. Dalam penelitian awal tersebut diperoleh bahwa sepanjang pemerintahan Orde Baru sedikitnya telah terdapat enam design politik utama sebagai alasan pembenar bagi tindak kekerasan negara yang dilakukan sepanjang 1965-1998, yaitu: ${ }^{16}$

a) Kebijakan menyatakan PKI sebagai dalang pembantaian dan kudeta disusul dengan pernyataan PKI sebagai partai terlarang. Era ini paling tidak sudah dimulai Soeharto sejak September 1965 hingga awal 1970. Operasi Trisula di Jawa Timur, Operasi Kalong di Jakarta dan operasi-operasi militer yang dimotori penguasa daerah militer setempat yang menghasilkan tidak kurang dari jutaan orang tewas dan jutaan orang hidup dalam tekanan, siksaan dan kesewenang-wenangan negara. Skenario terbunuhnya para jenderal termasuk Jenderal Yani, salah satu rival utama Soeharto di Angkatan Darat dan mandat operasi keamanan Surat Perintah 11 Maret 1966 yang manipulatif serta misterius adalah awal petaka dari rangkaian panjang peristiwa paling berdarah dalam sejarah kekerasan di Indonesia. ${ }^{17}$

15 Satya Arinanto, HAM Dalam Transisi Politik Indonesia, Depok: Pusat Studi Hukum Tata Negara, Fakultas Hukum, Universitas Indonesia, 2003, hal. 57.

16 Ahmad Hambali, "Kejahatan Kemanusian di Indonesia," Workshet Paper No.3, Jakarta: LPHAM, 2003.

17 Eep Saefulloh Fatah, "Mencari Dalang Gerakan 30 September 1965: Urgensi Rekonstruksi Sejarah Kita," < http://www.progind.net/modules/ 
b) Kebijakan mengontrol kekuatan Islam sebagai bahaya baru setelah PKI bagi kehidupan politik nasional. ${ }^{18}$ Pembersihan kelompok penentang pancasila sebagai asas tunggal yang genderang perangnya sudah dimulai sejak MPR menetapkan Pedoman Penghayatan dan Pengamalan Pancasila (P4) sebagai satu ketetapan politik nasional tahun 1978. Momentum tersebut kemudian di tindaklanjuti Orde Baru dengan seruan menjadikan Pancasila sebagai asas tunggal kehidupan sosial politik masyarakat di susul pernyataan provokasi dan intimidasi bagi para penentangnya yang disampaikan Soeharto pada bulan Maret-April 1980 di depan Rapim ABRI Riau dan prajurit Kopasandha (sekarang Kopassus) Cijantung Jakarta. Sejak ancaman dan intimidasi itulah kemudian terjadilah berbagai rangkaian terorisme negara terhadap para aktivis Islam diperistiwa Koman-

wfsection/article.php?articleid $=69>$, Diakses 14 Juni 2007.

18 Pernyataan ini pernah dilontarkan secara eksplisit oleh Panglima Kopkamtib, Jenderal Soemitro dalam biografinya yang mengatakan: “..terhadap Islam, pemerintah Orde Baru dan Angkata Darat khususnya, sejak awal menyadari tentang kemungkinan naiknya pamor politik kekuatan Islam. jatuhnya kekuatan ekstrim kiri PKI -yang kemudian secara formal diperkuat dengan keputusan pembubaran PKI- secara politis mengakibatkan naiknya pamor politik Islam sehingga terjadilah ketidakseimbangan. Sayap Islam yang sedang mendapat angin kemudian cenderung hendak memperkuat posisinya. Padahal disadari oleh Angkatan Darat ketika itu bahwa di dalam sayap Islam masih terdapat bibit-bibit ekstrimsime yang amat potensial. Sehingga policy umum militer ketika itu sebenarnya adalah menghancurkan kekuatan ekstrim kiri PKI dan menekan (bukan menghancurkan) sayap Soekarno pada umumnya, sambil amat berhati-hati untuk mencegah naiknya sayap Islam." Heru Cahyono, Pangkopkamtib Soemitro dan Peristiwa 15 Januari 1974, Jakarta: Sinar Harapan, 1998, hal. 46. do Jihad (1979), teror Warman di Raja Polah dan Cicendo yang disusul oleh sebuah drama pembajakan pesawat Woyla (1981), Kerusuhan Lapangan Banteng (1982), Kasus Priok (1984), Penangkapan aktivis Usroh (1986), Penyerbuan militer di dusun Talangsari Lampung (1989) dan penyerangan terhadap pesantren Abdul Manan di Haor Koneng Majalengka Jawa Barat (1991).

c) Kebijakan menjalankan kerjasama ekonomi-politik antara Indonesia, Amerika dan Australia untuk menginvasi Timor-Timur di tahun 1975. Berbagai pertemuan pendahuluan di tahun 19741975 dilakukan presiden Soeharto dengan presiden Amerika, Gerald Ford dan Perdana Menteri Australia, Gough Withlam secara intensif untuk mematangkan proses invasi yang dilaksanakan di awal bulan desember 1975. Inti dari itu semua adalah, tambahan wilayah berupa provinsi ke 27 bagi Indonesia, konsensi minyak bagi Australia di Celah Timor (Timor Gap), dan keberhasilan Amerika untuk memperluas basis wilayah politik perang dingin di Asia Tenggara dengan dikalahkannya kelompok kiri Fretilin di Timor-Timur.

d) Kebijakan melenyapkan para pengkritik dan kelompok atau perorangan yang bersikap oposan terhadap pemerintah. Implementasi dari kebijakan ini terlihat pada tindakan penculikan, penangkapan, penahanan bahkan pembunuhan yang terjadi antara 1965-1998.

e) Kebijakan mengendalikan berbagai kekuatan politik dan faksi baik personal maupun kelompok guna pengamanan kekuasaan dari potensi gangguan dan 
ancaman. Cara ini antara lain dilakukan dengan mendorong atau membiarkan konflik dan kekacauan sebagai trigger (picu) untuk bisa direspon dengan munculnya kebijakan represif negara. Kasus kerusuhan 15 januari 1974, bentrokan pada kampanye partai politik di Lapangan Banteng (1982), berbagai kerusuhan berbau sara di Tasikmalaya (1996) hingga kerusuhan Mei 1998, teror seperti pembunuhan atas nama dukun santet di Banyuwangi dan Ciamis.

f) Kebijakan menjaga kepentingan eksplotitatif Orde Baru terhadap sumber daya alam di beberapa daerah. Kebijakan ini biasanya dilangsungkan lewat kerjasama eksploitasi dengan pihak ketiga yang umumnya korporasi Amerika seperti dengan PT Freeport yang menguras habis tembaga dan emas di gunung Iceberg Papua bahkan hingga saat ini. Dan PT Exxon Mobil di Aceh. Kebijakan ini kemudian dikenal dengan nama capital violence, satu kekerasan yang disebabkan karena bertemunya kepentingan modal dan pemerintah despotik. ${ }^{19}$

\section{Penyelesaian Setengah Hati Pertanggung- jawaban Pelanggaran Berat HAM Masa \\ Lalu}

Upaya mendorong pertanggungjawaban atas kasus-kasus pelanggaran berat HAM rezim masa lalu merupakan bagian kecil dari gelombang penuntutan hak asasi manusia internasional, yang menjadi tren dan saling terkait

19 Ahmad Hambali, "Tiga Bentuk Kekerasan Negara," Makalah dipresentasikan dalam diskusi "Kebijakan Kekerasan Negara di Aceh," SMA BPK Penabur, Jakarta, 1999, hal. 1-3. dalam kampanye mendorong upaya pertanggungjawaban dari setiap negara terhadap kasus-kasus pelanggaran berat HAM masa lalu yang terjadi. Gelombang masyarakat dunia untuk menuntut upaya pertanggungjawaban kejahatan kemanusiaan rezim masa lalu disebut dengan istilah justice cascade (riam keadilan). Istilah justice cascade merupakan satu fenomena masyarakat diberbagai belahan dunia yang menuntut tanggungjawab pelanggar HAM berat (terutama pelanggaran HAM yang dilakukan oleh pihak militer dan kepolisian) yang terjadi di masa lalu dalam proses demokratisasi. ${ }^{20}$

Gerakan global ini menjadi signifikan ketika dalam tenggang waktu Januari 1990 hingga Mei 2008, terdapat tidak kurang dari 67 orang kepala negara yang dituntut ke pengadilan atas dugaan perbuatan kejahatan berat. ${ }^{21}$ Gagasan "justice cascade" ini pertama kali dicetuskan oleh Sikkink dan Ellen Lutz ${ }^{22}$ setelah melihat fenomena antara kuatnya impunitas pelaku dengan desakan para korban di Eropa Selatan dan Amerika Latin telah

20 Penggunaan istilah Cascade, merujuk pada perumpamaan mengalirnya air jeram yang melawan sikap para pimpinan politik, pejabat sipil maupun militer termasuk kepala negara yang melakukan pembantaian atau kejahatan terhadap kemanusiaan yang tidak dihukum dan hal itu dianggap hal yang lumrah terjadi. Mengalirnya air jeram (cascade) keadilan ini terus menerus menggulung membesar yang mendesak agar pelakunya diadili di pengadilan. Kathryn Sikkink, The Justice Cascade: How Human Rights Prosecutions Are Changing World Politics, (New York: W. W. Norton \& Company, Inc. 2012), hlm. 9.

${ }^{21}$ TOSA Hiroyuki, "Keadilan Transisional Yang Terabaikan? Tinjauan Ulang Masalah Indonesia/ Timor Leste", Kobe University, www2.kobe-u. ac.jp/ tosa/keadilan.pdf

22 Simona Tuţuianu, Towards Global Justice: Sovereignty in an Interdependent World, (New York: Springer Science \& Business Media, 2012), hlm. 238. 
menyebar ke seluruh dunia, fenomena ini tidak bisa dibantah menjadi gerakan menuntut pertanggungjawaban yang mulai menerjang negara-negara yang melindungi para pelaku pelanggaran berat HAM dengan cepat untuk menyapu bersama banyak aktor di belakang mereka.

Selama 1975-1990, dakwaan pertama terhadap pejabat negara dalam forum peradilan pidana terjadi di Yunani, Portugal, Argentina dan Guatemala. Proses hukum tersebut jelas mendapat penghadangan yang serius dari pelaku sehingga hampir tidak berhasil. Tahun 1990-2010, pertanggungjawaban pelanggaran berat HAM resmi menjadi bagian dari hukum dan mekanisme lembaga internasional. Namun begitu, PBB melalui Sekretarisnya, Ban Ki-Moon malah menyebut ada gelaja untuk menggantikan "new age accountability," dengan "old era of impunity." 23

Namun, "justice cascade" ini tidak tersebar secara merata dan sifat politik yang melekat pun juga berbeda, tergantung kasusnya (case by case). Sehubungan dengan itu, salah satu poin penting yang ditunjukkan oleh Sikkink \& Lutz, adalah pengaruh dari karakteristik proses transisi demokratisasi terhadap keadilan transisi. Misalnya, terjadinya transisi terputus ("ruptured" transition) seperti di Yunani, Portugis dan Argentina, disebabkan oleh pengaruh elit politik rezim lama yang telah lenyap, sehingga terbuka peluang mengadili pelanggar HAM di

23 Kathryn Sikkink, "The Age of Accountability The Global Rise of Individual Criminal Accountability, " dalam Francesca Lessa, Leigh A. Payne, Amnesty In the Age of Human Rights Accountability: Comparative and International Perspectives, (Cambridge: Cambridge University Press, 2012), hlm. 19. masa lalu oleh badan yudisial. Akan tetapi, jika transisi paket ("pacted" transition) berupa hasil kompromi antara para elit rezim lama dengan pihak pro demokratisasi seperti di Spanyol dan Uruguay, sebab pengaruh elit rezim lama masih cukup besar, sehingga para pelaku pelanggaran HAM cenderung dibebaskan dari ancaman hukuman pidana lewat pemberian amnesti, sehingga kejahatan masa lalu tidak dipersoalkan lagi. ${ }^{24}$

Di Indonesia, Komnas HAM sebagai institusi penyelidik resmi kasus-kasus pelanggaran berat HAM telah mengidentifikasi bahwa setidaknya terdapat 13 Kasus Pelanggaran HAM yang diduga dilakukan Soeharto. ${ }^{25}$ Namun demikian untuk pelanggaran berat HAM Soeharto, pertanggungjawaban yang dilaksanakan tidak sempurna dan parsial yaitu baru dilakukan untuk kasus pelanggaran berat HAM Tanjung Priok itupun pada prakteknya, pengadilan HAM yang dibentuk menjadi 'kuburan keadilan' yang diharapkan para korban karena pengadilan gagal mewujudkan serangkaian keadilan dan kebenaran dengan cacat teknis dan independensi di sana-sini. ${ }^{26}$

Era politik transisi paska jatuhnya Soeharto tidak satupun mampu menyelesaikan pertanggungjawaban kasus-kasus pelanggaran berat HAM masa lalu tersebut secara adil dan patut. Empat presiden yang datang silih

24 Naomi Roht-Arriaza, Javier Mariezcurrena, Transitional Justice in the Twenty-First Century: Beyond Truth versus Justice, (Cambridge: Cambridge University Press, 2006), hlm. 307.

25 Kompas, "Komnas HAM Identifikasi 13 Kasus Pelanggaran HAM yang Diduga Dilakukan Soeharto", Rabu, 16 Oktober 2002

26 Kelompok Kerja Pemantau Pengadilan Hak Asasi Manusia, "Pengadilan Yang Melupakan Korban: Laporan Pemantauan," Jakarta: ELSAM, KontraS, PBHI, 24 Agustus 2006, hal. 3-13. 
berganti hanya sibuk dengan pendemonstrasian konsep dan karakter kekuasaan sesuai dengan pemahamannya tentang sejauh mana moralitas pertanggungjawaban perlu menjadi kerangka hubungan antara kekuasaan dengan menjalankan kewajiban bagi masyarakat banyak.

Ironisnya, tidak satupun pengalaman kemanusiaan para presiden yang memberikan kontribusi betapa pentingnya membangun masa depan dengan menunjukkan sebuah pertanggungjawaban terlebih dahulu. Akibatnya, kebijakan negara tidak hanya ditarik kuat oleh berbagai kepentingan tapi juga selalu muncul setengah hati, tidak tuntas dan tidak berakhir dengan evaluasi dan pertanggungjawaban.

Sejak Habibie didaulat Soeharto meneruskan 'kursi panas' kepresidenan, berbagai kebijakan penegakan HAM dicoba digelontorkan. Tujuannya bisa jadi diarahkan untuk meredam amarah nasional terhadap despotisme orde baru yang mulai terkuak. Tidak hanya memasukan berbagai agenda HAM dalam kebijakan ketatanegaraan, presiden yang teknokrat ini juga merespon berbagai perkembangan internasional dengan meratifikasi Convention Against Torture dan Convention Elimination Against Racial And Discrimination serta berbagai kebijakan nasional lainnya. Presiden Habibie hanya mampu menggelar pengadilan koneksitas Kasus Teungku Bantaqiah dan Pengadilan Militer Kasus Trisakti, itupun tidak menghasilkan keadilan yang ingin dicapai.

Di era presiden Gus Dur yang secara umum mulai mempelopori reformasi birokrasi dengan membubarkan lembaga extra judicial tentara bakorstanas yang dulu ber- nama Kopkamtib, memisahkan Polri dari ABRI, serangkaian kebijakan dan upaya pertanggungjawaban cukup baik dilakukan. Hal tersebut antara lain dilakukan dengan:

1) Memfasilitasi terbentuknya pengadilan HAM dengan mengeluarkan Perpu No. 1 Tahun 2000 tentang Pengadilan HAM.

2) Memfasilitasi pengungkapan pelanggaran HAM berat di Timtim dengan membentuk KPP HAM Tim-tim.

3) Menguatkan pembentukan pengadilan HAM dengan mengeluarkan Pengadilan HAM (UU 26 Tahun 2000).

4) Menggelar Pengadilan HAM ad hoc Kasus Timor Timur

Pada era pemerintahan Megawati, kebijakan perang kembali diterapkan secara terang-terangan dalam bentuk Darurat Militer, tertib sipil dan status lain di Aceh, akibatnya pertanggungjawaban pelanggaran berat HAM masa lalu otomatis tidak mendapat tempat sebagaimana mestinya. Dengan kondisi tersebut, maka dapat dikatakan tidak begitu signifikan atau hampir tidak ada yang berubah, bahkan represi dan pembunuhan politik mulai akrab kembali ditelinga masyarakat melalui terbunuhnya aktivis HAM Munir. Dengan munculnya skandal keji itu, era transisi bukan hanya telah dibajak tapi juga telah dipaksa berbalik arah mengikuti para penikmat status impunitas yang memang menginginkan kejayaan masa lalu mereka dapat kembali dan jaminan rasa aman mereka dari jerat hukum dan keadilan diperoleh.

Tidak kunjung munculnya kesadaran pemerintah termasuk pada masa pemerintahan presiden Susilo Bambang Yudhoyono 
untuk melaksanakan pertanggungjawaban kasus-kasus kejahatan masa lalu membuat salah satunya para pelakunya merasa kebal hukum dan bebas mengulang kejahatannya pada masa datang. Warga negara seperti $\mathrm{Mu}-$ nir telah menjadi korban dari tindakan pembunuhan yang diduga kuat dilakukan oleh pelaku-pelaku lama. Tidak hanya itu pelaksanaan pertanggungjawaban kasus masa lalu secara adil dan patut kembali gagal digelar. Pemerintahan Yudhoyono hanya mampu melaksanakan beberapa pertanggungjawaban setengah hati yang miskin dari keadilan dan tujuan-tujuan sejati dari sebuah pertanggungjawaban seperti pada:

1) Pengadilan Militer Kasus Theys Eluay;

2) Pengadilan Koneksitas Kasus 27 Juli 1996;

3) Pengadilan HAM ad hoc Kasus Tanjung Priok yg salah satu putusannya adl memberikan kompensasi kepada korban;

4) Mulai digelarnya Pengadilan HAM Kasus Aberpura;

5) Putusan banding dan kasasi Pengadilan HAM ad hoc Kasus Timor Timur ;

6) Pengadilan militer untuk kasus Semanggi I;

7) Banding Pengadilan HAM ad hoc Kasus Tanjung Priok; dan

8) Melanjutkan Pengadilan HAM Kasus Aberpura.

Dengan demikian, dapat disimpulkan bahwa komitmen negara dalam menerapkan kebijakan untuk mempertanggungjawabkan kasus-kasus kejahatan negara selalu tak tuntas dan gagal. Ketiadaan konsep, komitmen, konsistensi dan kerjasama termasuk dalam menghadapi gangguan yang timbul ternyata semakin terlihat. Bahkan negara dalam hal ini telah menjadi save player dengan memilah berbagai langkah aman menjalankan agenda penegakan HAM dengan tidak berbenturan dengan penyakit akut dan mencuci dosa dalam dirinya.

Kebijakan ini, sesaat seperti mengandung kebaikan. Namun faktanya adalah sebaliknya. Satu demi satu, dosa dan kerusakan pada tubuh birokrasi seperti suap, makelar kasus, gelombang korupsi pejabat tinggi negara menyeruak kepermukaan menuntut penyelesaian dan pengobatan. Di tempat lain, kekerasan dianggap sebagai cara terbaik penanganan suatu masalah, dialog dan mediasi dianggap sebagai suatu yang usang dan bukan menjadi jalan terbaik penyelesaiaan bagi siapapun. Di level tertinggi, jeratan hukum bagi petinggi hanya menjadi wacana mainan dalam menggertak lawan politik. Keberpihakan pada keadilan semata-mata dilakukan hanya untuk mengintimidasi para pihak yang bersebarangan atau menjadi serangan balik.

Dengan serangkaian fenomena tersebut, maka amatlah wajar bila negeri ini tak pernah mampu melepaskan dirinya dari rouge cyclus bahkan untuk soal-soal remeh temeh. Selain tak beralaskan pada pijakan yang kuat, pemerintah cenderung tidak pernah mau menyatakan dirinya untuk serius, berani dan lurus dalam menyelesaikan berbagai persoalan mendasar bangsa ini yang hampir kesemuanya terletak pada warisan masa lalu.

Pelaksanaan Pertanggungjawaban sebagai Hak Konstitusional Korban Pelanggaran Berat HAM Masa Lalu

Dalam era post-Soeharto, kegagalan para pemimpin nasional untuk menangani ketidaka- 
dilan ekonomi, berlanjutnya penggunaan kekuatan militer untuk menghadapi para pemrotes, pengerahan kekuatan paramiliter oleh elit, dan kegagalan penegakan hukum, membuat rakyat semakin apatis dan lebih cenderung suka melakukan tindakan sendiri dalam menyelesaikan masalahnya. Gabungan keadaan inilah yang menurut Elizabeth Fuller Collins, mantan Direktur Program Kajian Asia Tenggara, serta Associate Professor, Department of Philosophy, Ohio University ini, menimbulkan budaya kekerasan di masyarakat sebagai jawaban dari apatisme publik terhadap kegagalan pencapaian cita-cita welfare state (negara kesejahteraan). ${ }^{27}$

Sikap apriori masyarakat tentu saja tidak timbul dalam setahun-dua-tahun belakangan ini. Perilaku tersebut juga lahir karena ketika era transisi yang diharapkan dapat berlangsung lebih baik ternyata tampil tanpa visi dan konsep yang jelas, sehingga memicu berbagai keberlangsungan kerusakan yang lebih masif. ${ }^{28}$ Karena pertanggungjawaban sesungguhnya merupakan keniscayaan dari sebuah tindakan, maka secara lebih rinci, kepentingan pertanggungjawaban negara dalam kasus-kasus pelanggaran berat HAM masa lalu, antara lain terlihat dari: ${ }^{29}$

Pertama, mendorong terwujudnya pengungkapan kebenaran sejarah bangsa atas berbagai peristiwa kelam masa lalu se-

27 Elizabeth Fuller Collins, "Indonesia: Sebuah Budaya Kekerasan?", Asian Survey, vol. XIII No. 4, (Juli/Agustus 2002): hal. 582-604. Diterjemahkan oleh Nico Harjanto dan Putut Widjanarko.

28 Vhrmedia Online, "10 Tahun Reformasi Berjalan Tanpa Konsep," < $\underline{\text { http://www.vhrmedia.com/vhr- }}$ news/berita, 10-Tahun-Reformasi-Berjalan-Tanpa-Konsep-1734.html>, Diakses 21 Mei 2008.

29 Ahmad Hambali, "Melapangkan Jalan Bagi Rekonsiliasi," Makalah Diskusi Uji Publik Calon Anggota Komisi Kebenaran dan Rekonsialiasi, Departemen Hukum dan HAM RI, 2006., hal. 3-4. cara faktual, transparan, adil dan kredibel. Dengan misi ini, sejarah tidak hanya dicatat sebagai sebuah fakta yang telah berlangsung, tapi lebih dari itu, sejarah juga menjadi bagian penting dari sebuah peradaban masyarakat yang dapat di ambil hikmah dan pelajarannya dari masa lalu demi membangun kehidupan yang lebih baik.

Kedua, memfasilitasi terwujudnya pencairan ketegangan dan dendam sosial-politik korban, pelaku, saksi dan berbagai pihak yang pernah terlibat di dalamnya sebagai salah satu pra-syarat yang dapat melapangkan jalan menuju rekonsiliasi. Oleh karena itu, dibutuhkan juga pernyataan pengakuan negara (official convention) tentang eksistensi dan penghargaan martabat para korban sebagai salah satu bagian penting dari warga bangsa. Misi ini sekaligus merupakan penegasan pemerintah tentang betapa berartinya suara korban tidak hanya bagi pemulihan eskalasi psiko-traumatik yang bertahun-tahun mereka derita tapi juga bagi pencatatan fakta sejarah bangsa yang selama ini nyaris tak terucapkan (unspeakable truth). Pencarian ketegangan hanya muncul oleh proses pengungkapan kebenaran yang tulus diikuti oleh pengakuan maaf yang ikhlas dan rendah hati atas terjadinya kekeliruan dan kesengajaan peristiwa tersebut. Sebab pada dasarnya, maaf hanya mungkin dilakukan bila bangsa ini tahu akan perstiwa yang membuatnya harus meminta maaf. Bagaimana bisa maaf itu meluncur dari kata hati dan mulut negara, padahal bangsa ini tidak pernah mengetahui mengapa dan untuk perkara apa ia harus meminta maaf.

Ketiga, mendorong terwujudnya jalan dan komitmen yang konsisten bagi pence- 
gahan berulangnya sebuah kejahatan kemanusiaan dan berbagai tindak kekerasan negara. Dengan begitu, dipertanggungjawabkannya berbagai kebijakan kekerasan negara masa orde baru, diharapkan dapat menjadi titik awal bagi setiap pelaku kekerasan negara untuk segera menghentikan segala bentuk tindakan yang melawan martabat kemanusiaan dengan alasan apapun di masa selanjutnya. Keberhasilan misi ini menjadi sangat vital bagi keberhasilan upaya pencarian kebenaran secara keseluruhan. Mendorong sebuah rekonsiliasi saja, berpotensi akan hancur bersamaan dengan terulangnya kembali sebuah tindak pelanggaran HAM.

Di masa lalu, Kopkamtib di ubah menjadi Bakorstanas untuk kemudian dibubarkan oleh sebuah momentum transisi reformasi yang dikehendaki oleh rakyat. Sayangnya publik tidak mendapat penjelasan yang cukup apa dan mengapa lembaga semacam Kopkamtib berubah menjadi Bakorstanas dan pada akhirnya memang harus dibubarkan. Padahal, menurut beberapa kajian, perubahan yang akhirnya berujung pada pembubaran lembaga semacam Kopkamtib dan Bakorstanas tidak didasari oleh alasan apapun kecuali karena desakan dan keniscayaan bahwa lambat laun negara harus segera menghentikan produksi kekerasan terutama dengan menggunakan lembaga negara baik lembaga sipil maupun militer sebagai mesin kekerasannya. Disertasi Tanter mengenai Negara Intelijen Orde Baru dapat menjadi rujukan bahwa pemerintahan Suharto menjadikan lembaga tersebut sebagai pelaksana utama kekerasan negara.

Keempat, memfasilitasi terwujudnya sistem, aparat dan tata pemerintahan yang bersih dan berwibawa yang menghargai dan melindungi hak-hak setiap warga negara serta nilai-nilai kemanusiaan. Kemampuan negara untuk merehabilitasi dirinya dari penyakit dan virus birokrasi yang selama ini masih menjangkiti sebagian besar jajaran pemerintahan terutama sektor pertahanan dan keamanan adalah menjadi bagian yang komplementer dengan membangun masa depan bangsa yang lebih baik. ABRI memang telah dipisahkan menjadi TNI dan Polri, tapi kultur dan prilaku tidak sepenuhnya berhasil tereformasi oleh perubahan struktur tersebut. Residu perilaku kekerasan dikedua institusi pertahanan dan keamanan tersebut terus berlangsung bukan hanya ditujukan kepada rakyat tetapi juga terjadi antara sesama mereka. Akibatnya reformasi seadanya terhadap kedua institusi tersebut kian hari kian terungkap kegagalannya. Hanya perumusan yang sungguh-sungguh dan benar yang lambat laun akan menciptakan sistem, aparat dan tata pemerintahan yang bersih dan berwibawa yang menghargai dan melindungi hak-hak setiap warga negara serta nilai-nilai kemanusiaan salah satunya melalui tahapan yang didahului oleh pengungkapan kebenaran.

Kelima, mendorong terciptanya kesadaran masyarakat akan arti penting sebuah pendidikan dan pengetahuan publik untuk lebih mematangkan pemahaman dan partisipasi masyarakat dalam menghadapi segala persoalan bangsa. Masyarakat, dalam kerangka kerja pertanggungjawaban kebijakan negara ini memang harus mengambil posisi menjadi pemain utama. Agar muncul peran signifikan masyarakat yang tidak hanya sebagai elemen utama pencegah terjadinya 
tindak pelanggaran HAM, tapi juga sebagai kunci penentu keberhasilan seluruh tujuan dari upaya tersebut. Tidak bisa dipungkiri bahwa masyarakat merupakan salah satu pihak yang menyebabkan orde baru bisa mengawali dan selanjutnya melestarikan kekerasan di negeri ini selama lebih dari tiga dekade. Setiap kekerasan yang dilakukan orde baru terus direspon oleh sikap diam sehingga membantu menjadi sebuah kejahatan umum yakni kejahatan kebisuan. Akibatnya kekerasan orde baru seakan menjadi bagian dari tindakan dan model sah cara pemerintahan dalam melaksanan pembangunan.

Dari serangkaian arti penting tersebut, maka sudah selayaknya pemerintah secara benar, adil dan patut melaksanakan penegakan hukum tanpa pandang bulu termasuk terhadap berbagai kasus masa lalu yang belum atau tidak pernah dipertanggungjawabkan. Keharusan pemerintah dalam melaksanakan pertanggungjawaban itu juga 'dipaksa' oleh Konstitusi yang dalam Pasal 28I ayat (2) ditegaskan agar setiap orang berhak bebas dari perlakuan yang bersifat diskriminatif atas dasar apa pun dan berhak mendapatkan perlindungan terhadap perlakuan yang bersifat diskriminatif itu. Dengan demikian, pengabaian pemerintah atas upaya pelaksanaan pertanggungjawaban pelanggaran berat HAM masa lalu baik secara sengaja maupun karena kelalaian bukan hanya berdampak pada nasib jutaan korban dan kredibelitas bangsa ini tapi juga berimplikasi pada jatuhnya tuduhan bahwa pemerintah telah secara nyata mengabaikan atau membangkang terhadap ketentuan Konstitusi. Padahal bila hal tersebu terjadi, maka secara ketatanegaraan, Majelis Permusyawaratan Rakyat (MPR) dapat menjadikannya sebagai dasar pemakzulan atas dasar sikap diskriminasi negara terhadap upaya meminta penyelesaian pertanggungjawaban pelanggaran berat HAM yang dituntut para korban.

Sebagai bagian dari ketentuan Konstitusi, Pasal 28I ayat (2) UUD NRI 1945 merupakan salah satu pasal yang dibahas dalam agenda reformasi konstitusi 1999-2002 khususnya dalam perumusan pengaturan mengenai hak asasi manusia yang diputuskan dalam Rapat Paripurna ST MPR-RI ke-9, 18 Agustus 2000. ${ }^{30}$ Pembentukan pasal anti diskriminasi ini juga dikuatkan oleh adanya ketentuan universal untuk melarang segala bentuk diskriminasi sebagaimana disebutkan dalam Pasal 7 Deklarasi Umum Hak Asasi Manusia (DUHAM) PBB yang menyatakan:

Semua orang sama di depan hukum dan berhak atas perlindungan hukum yang sama tanpa diskriminasi. Semua berhak atas perlindungan yang sama terhadap setiap bentuk diskriminasi yang bertentangan dengan Deklarasi ini, dan terhadap segala hasutan yang mengarah pada diskriminasi semacam ini.

Selain itu, penegasan mengenai sikap dan kebijakan pemerintah untuk menolak diskriminasi juga telah diwujudkan dengan dirumuskannya RANHAM yang melatarbelakangi ratifikasi pemerintah Indonesia terhadap Konvensi Internasional PBB mengenai penghapusan diskriminasi rasial pada 25 Mei 1999. Ratifikasi dilakukan melalui UU No. 29 Tahun 1999 tentang Pengesahan International Convention on the Elimina-

30 Nur Rosihin Ana et. al. Naskah Komprehensif Perubahan Undang-Undang Dasar Negara Republik Indonesia Tahun 1945: Latar Belakang, Proses dan hasil Pembahasan 1999-2002, Jakarta: Sekjen MK RI, 2010, hlm. 356 dan 361. 
tion of All Forms of Racial Discrimination 1965 (Konvensi Internasional tentang Penghapusan Segala Bentuk Diskriminasi Rasial 1965).

Pencegahan diskriminasi dalam berhadapan dengan hukum dan tuntutan keadilan bagi setiap masyarakat, secara eksplisit dimuat dalam Pasal 17 UU No. 39 Tahun 1999 tentang Hak Asasi Manusia (UU HAM) yang menegaskan:

"Setiap orang, tanpa diskriminasi, berhak untuk memperoleh keadilan dengan mengajukan permohonan, pengaduan, dan gugatan, dalam perkara pidana, perdata, maupun administrasi serta diadili melalui proses peradilan yang bebas dan tidak memihak, sesuai dengan hukum acara yang menjamin pemeriksaan yang obyektif oleh hakim yang jujur dan adil untuk memperoleh putusan yang adil dan benar."

Persamaan hak semua orang untuk memperoleh keadilan dalam UU HAM tidak hanya diatur dalam Pasal 17 saja tapi juga diatur dalam pasal 18 hingga 19. Ketiga pasal mengenai hak memperoleh keadilan tersebut mencakup: hak tanpa disskriminasi atas perlindungan hukum; hak atas keadilan dalam proses hukum dan hak atas hukuman yang adil. Ketentuan ini semakin menegaskan bahwa pengabaian negara terhadap tuntutan pertanggungjawaban pelanggaran berat HAM masa lalu yang selama ini disuarakan oleh korban dan masyarakat tidak hanya melanggar ketentuan undang-undang tapi juga melawan kehendak konstitusi. Pelanggaran negara atas undang-undang dan konstitusi ini jelas memiliki dampak yang serius bagi eksistensi presiden. Hal ini karena konstitusi menjadi bagian tak terpisahkan dari acuan utama pemerintah dalam menjalankan pembangunan termasuk pembangunan hukum dan kewajiban negara atas HAM bagi warga negara yang melarang untuk berlaku diskriminatif.

Dengan demikian, tindakan diskriminatif pemerintah dalam merespon tuntutan penyelesaian pertanggungjawaban kasus-kasus pelanggaran berat HAM masa lalu dapat dijadikan alasan pemakzulan disebabkan tidak dilaksanakannya ketentuan Pasal 28I ayat (2) UUD NRI 1945. Proses pemakzulan ini setidaknya melibatkan Dewan Perwakilan Rakyat (DPR), Majelis Permusyawaratan Rakyat (MPR) dan diputuskan oleh Mahkamah Konstitusi (MK).

\section{PENUTUP}

Salah satu beban berat bangsa Indonesia paska reformasi adalah ketidakmampuan pemerintahan sesudahnya dalam memisahkan masa lalu dengan masa kini melalui sebuah mekanisme pencarian keadilan di era transisi. Akibatnya beban tersebut semakin menggumpal dan menumpuk mengganjal perjalanan bangsa ini. Faktanya, sejak pemerintahan orde baru yang didalamnya banyak terjadi peristiwa pelanggaran berat HAM, berakhir, tidak satupun pemerintahan sesudahnya menjalankan kewajiban dan prinsip penyelesaian pertanggungjawaban pelanggaran berat HAM masa lalu secara benar, adil dan patut.

Undang-Undang Dasar Negara Republik Indonesia Tahun 1945 sebagai pucuk hukum tertinggi (highest law) tidak hanya menjadi simbol dari keberadaan Indonesia sebagai negara hukum tapi juga menjadi dasar dari setiap tindakan negara yang tidak hanya harus berdasarkan hukum dalam menjalank- 
an pemerintahannya tapi juga kewajiban menjalankan hukum tanpa pandang bulu dan membeda-bedakannya atas dasar apapun. Oleh karena itu, tidak boleh ada satupun dari janji konstitusi yang dapat dilanggar pemerintah apalagi hal tersebut terkait dengan kewajiban penegakan hukum dalam kerangka negara hukum dan prinsip hak asasi manusia yang salah satunya adalah tentang hak untuk tidak diperlakukan diskriminatif yang secara jelas dinyatakan tegas dalam konstitusi. Pengabaian terhadap ketentuan dan aturan Konstitusi khususnya bagi pemerintah akan berimplikasi munculnya gugatan pelanggaran hukum paling serius yang menyebabkan pemakzulan.

\section{BIBLIOGRAFI}

G. Dwipayana dan Ramadhan KH. (1989). Soeharto: Pikiran, Ucapan dan Tindakan Saya. Jakarta: Citra Lamtoro Gung Persada.

Heru Cahyono. (1998). Pangkopkamtib Soemitro dan Peristiwa 15 Januari 1974. Jakarta: Sinar Harapan,

Kathryn Sikkink. (2012). The Justice Cascade: How Human Rights Prosecutions Are Changing World Politics. New York: W. W. Norton \& Company, Inc.

Kathryn Sikkink. (2012). "The Age of Accountability The Global Rise of Individual Criminal Accountability", dalam Francesca Lessa, Leigh A. Payne, Amnesty In the Age of Human Rights Accountability: Comparative and International Perspectives. Cambridge: Cambridge University Press.

Naomi Roht-Arriaza. Javier Mariezcurrena, (2006). Transitional Justice in the Twenty-First Century: Beyond Truth versus Justice. Cambridge: Cambridge
University Press,

Nur Rosihin Ana. (2010). et. al. Naskah Komprehensif Perubahan Undang-Undang Dasar Negara Republik Indonesia Tahun 1945: Latar Belakang, Proses dan Hasil Pembahasan 1999-2002. Jakarta: Sekjen MK RI.

Richard Tanter. (1991). Intelligence Agencies and Third World Militarization: A Case Study of Indonesia. Dept. of Politics Faculty of Economic and Politics Monash University.

Robert Mohl. (1973). Two Concepts of the Rule of Law. Indianapolis: Liberty Fund Inc.

Satya Arinanto. (2003). HAM Dalam Transisi Politik Indonesia. Depok: Pusat Studi Hukum Tata Negara, Fakultas Hukum, Universitas Indonesia,

Simona Ţuţuianu. (2012). Towards Global Justice: Sovereignty in an Interdependent World. New York: Springer Science \& Business Media.

Sukmawati Sukarno. (2011). Creeping coup d'etat Mayjen Suharto: Kesaksian Hari-Hari Terakhir Bersama Bapak. Jakarta: Yayasan Bung Karno.

\section{Jurnal dan Makalah:}

Ahmad Hambali. (1999). "Tiga Bentuk Kekerasan Negara," Makalah dipresentasikan dalam diskusi "Kebijakan Kekerasan Negara di Aceh," SMA BPK Penabur, Jakarta. (2003). "Kejahatan Kemanusian di Indonesia." Workshet Paper No.3, Jakarta: LPHAM, . (2006). "Melapangkan Jalan Bagi Rekonsiliasi." Makalah Diskusi Uji Publik Calon Anggota Komisi Kebenaran dan Rekonsialiasi, Departemen Hukum dan HAM RI,

Elizabeth Fuller Collins. (2002). "Indonesia: Sebuah Budaya Kekerasan?”, Asian 
Survey, Diterjemahkan oleh Nico Harjanto dan Putut Widjanarko. Vol. XIII No. 4, Juli-Agustus 2002.

Peter Dale Scott. (1985). "The United States and the Overthrow of Sukarno," 19651967." Pacific Affairs, 58.

Tosa Hiroyuki. (2013). "Keadilan Transisional yang Terabaikan? Tinjauan Ulang Masalah Indonesia/Timor Leste." Kobe University, www2.kobeu.ac.jp/ tosa/keadilan.pdf

\section{Laporan-Laporan:}

Kelompok Kerja Pemantau Pengadilan Hak Asasi Manusia, (2006). “ Pengadilan Yang Melupakan Korban: Laporan Pemantauan," Jakarta: ELSAM, KontraS, PBHI, 24 Agustus.

Laporan Komnas HAM. (2003). "Pengkajian Pelanggaran HAM Orde Baru." Jakarta: Komnas HAM.

Laporan Koalisi NGO HAM Aceh. (2000). "Pola Pelanggaran HAM Aceh masa
DOM." Aceh: Koalisi NGO HAM Aceh.

Laporan KontraS, (2000). "27 Juli sebagai Kerusuhan Sistematis." Jakarta: Kont$\mathrm{raS}$,

Media Masa dan Internet:

Kompas, "Komnas HAM Identifikasi 13 Kasus Pelanggaran HAM yang Diduga Dilakukan Soeharto", Rabu, 16 Oktober 2002

Vhrmedia Online, "10 Tahun Reformasi Berjalan Tanpa Konsep," < $\underline{\text { http://www. }}$ vhrmedia.com/vhr-news/berita, 10-Tahun-Reformasi-Berjalan-Tanpa-Konsep-1734.html>, diakses 21 Mei 2008.

Wikipedia, "Orde Baru," $<$ http://id. wikipedia.org/wiki/Orde baru, > 10 Juli 2015.

Eep Saefulloh Fatah. "Mencari Dalang Gerakan 30 September 1965: Urgensi Rekonstruksi Sejarah Kita," < http://www. progind.net/modules/wfsection/article. php?articleid=69>, 14 Juli 2015. 